\title{
Diacronie
}

Studi di Storia Contemporanea

$N^{\circ} 16,4 \mid 2013$

Le monarchie nell'età dei nazionalismi

\section{La gracia real bajo la forma republicana en el Rio de la Plata. Vecindad y naturaleza en el litoral rioplatense (1808-1824)}

\section{Fabricio Gabriel Salvatto}

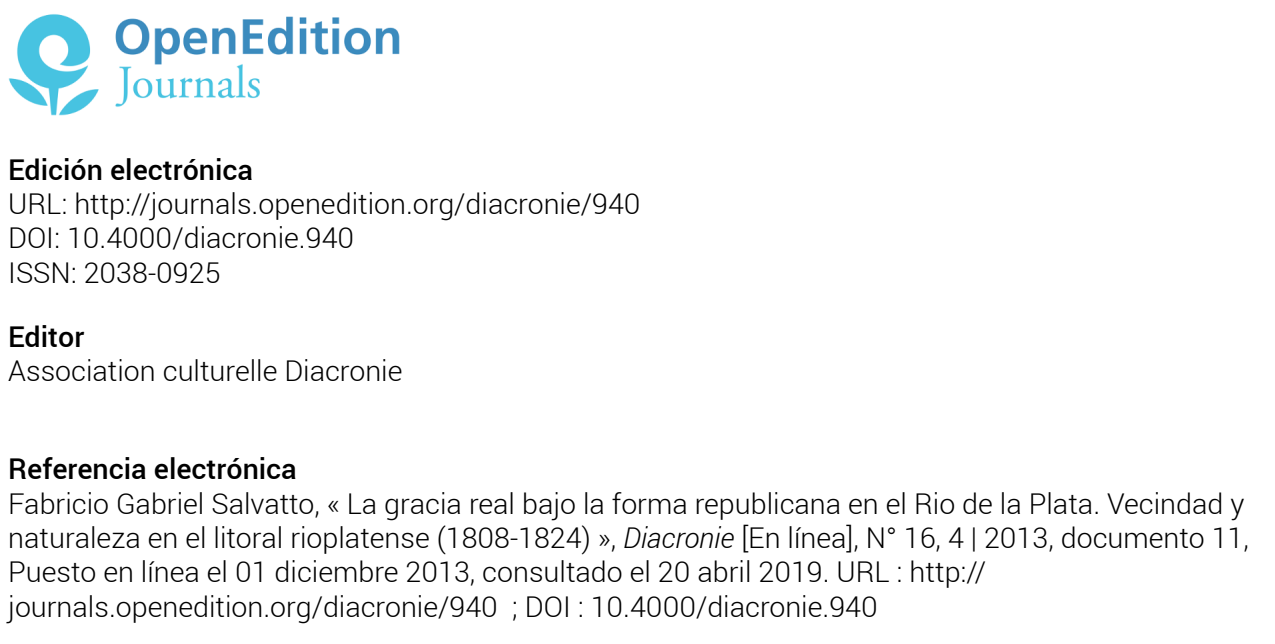

Creative Commons License 


\section{Diacronie}

\section{1/}

\section{La gracia real bajo la forma republicana en el Rio de la Plata}

Fabricio Gabriel SALVATTO *

Se ha propuesto que en el Río de la Plata la vecindad corporativa se fue convirtiendo progresivamente - entre 1810 y 1853 - en una ciudadanía abstracta. Sin embargo, encontramos en momentos clave de este proceso, formas de inclusión y de exclusión que definen al conjunto de los miembros permanentes de la comunidad basadas en las antiguas relaciones rey-súbdito. Un ejemplo de ello lo vemos en el reemplazo de la gracia real por el de las autoridades constituidas y constituyentes que se atribuyen una representación nacional (1815-1819) o en congreso nacional (1821-1824). Proponemos que los procesos abiertos entre 1808 y 1824 produjeron innovaciones en la ciudadanía política rioplatense, pero que aquellas fueron canalizadas por las experiencias conocidas bajo la monarquía a ambos lados del Atlántico.

\section{Introducción}

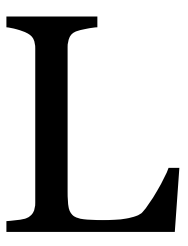

as formas de representación política en el Río de la Plata desde la crisis de la monarquía española en 1808 hasta el final de la Guerra de Independencia (1825) han sido analizadas señalando las alternativas monárquicas ${ }^{1} \mathrm{y}$ republicanas que se plantearon en este espacio hispanoamericano a fin de explicar el restablecimiento de las relaciones entre los cuerpos superiores de gobierno y las diferentes comunidades políticas emergentes. La historiografía de finales del siglo XIX, en plena consolidación del Estado Nacional argentino, hizo hincapié en los orígenes republicanos desde los primeros ensayos independientes. Durante el siglo XX

\footnotetext{
${ }^{1} \mathrm{Al}$ respecto algunos trabajos han llegado a plantear la idea de unos "reyes que no fueron"; éste concepto es bien resumido por: LOZIER ALMAZÁN, Bernardo, Proyectos monárquicos en el Río de la Plata, Los reyes que no fueron, Buenos Aires, Sanmartino, 2011.
} 
gran parte de la producción historiográfica sobre la historia rioplatense ha abordado el concepto de nación en función del problema del Estado contemporáneo, de la existencia de una Nación Argentina que se insinuaba en el marco territorial del actual estado-nación desde la revolución de mayo y del proceso de independencia de la antigua metrópoli. Las ideas modernas de Estado, constitución, soberanía, identidad, nacionalidad, han constituido elementos claves al momento de analizar la crisis del imperio español y la construcción de un nuevo sujeto histórico, el ciudadano, que remplazaría a los súbditos del Antiguo Régimen en el ámbito de lo que había sido el virreinato del Río de la Plata.

Si bien la historiografía de las últimas décadas ha criticado estas miradas y ha reconocido que esta ciudadanía estaba anclada en la vecindad del Antiguo Régimen, ambas nociones parten de un modelo explicativo que hace del derecho positivo, las constituciones nacionales y el principio democrático de igualdad ante la ley, ejes articuladores del proceso. De este modo, se han dejado al margen del análisis otras posibles variables provenientes de la noción de natural y de su oposición a la de extranjero, elementos fundamentales para la inclusión o exclusión de aquello que constituye el conjunto de los privilegios civiles y políticos durante el Antiguo Régimen. No se ha reparado en que estos elementos subsistirán e irán reapareciendo en los rasgos que adquirirá la ciudadanía en el Río de la Plata a principios de la década de 1820.

Se ha propuesto así, que en el Río de la Plata la vecindad corporativa se habría ido convirtiendo progresivamente - entre 1810 y la Constitución de 1853 - en una ciudadanía abstracta ${ }^{2}$. Sin embargo, encontramos en momentos clave de este proceso, formas de inclusión y de exclusión que definen a los miembros permanentes de la comunidad, basadas en las antiguas relaciones rey-súbdito. Un ejemplo de ello lo vemos en el reemplazo de los privilegios reales por las facultades de las autoridades constituidas y constituyentes.

\footnotetext{
${ }^{2}$ François-Xavier Guerra ha señalado que el ciudadano moderno ha sido caracterizado por los atributos de universalidad, igualdad e individualidad, según lo había planteado Pierre Rosanvallon. F. X, Guerra agrega además, el atributo de abstracción, cuya realización está contenida en las constituciones de las nuevas naciones americanas. Esta figura de ciudadano contrasta con la del vecino del Antiguo Régimen porque mientras el primero es parte de una colectividad abstracta, que solo cobra sentido en una sociedad política nueva, mientras que el vecino supone un criterio de definición específico: es un hombre concreto, enraizado y con una filiación territorial y/o corporativa, racial y específica. Véase ROSANVALLON, Pierre, La consagración del ciudadano. Historia del sufragio universal en Francia, México, Instituto Mora, 1999, pp. 12; GUERRA, François Xavier, «El soberano y su reino», in SÁBATO, Hilda, (Coord.), Ciudadanía política y formación de las naciones. Perspectivas históricas de América Latina», México, Fondo de Cultura Económica, 1999, pp. 42.
} 
La influencia de las formas institucionales propias de la monarquía española en el Río de la Plata ha sido abordada principalmente en el estudio de los proyectos monárquicos que fueron rechazados tanto por la opinión pública rioplatense como por los príncipes europeos a los que se les hizo tal oferta ${ }^{3}$. También se han comparado las prerrogativas monárquicas con las aspiraciones centralistas de Buenos Aires desde la revolución de Mayo hasta la desaparición del Régimen de Intendencias entre 1819 y 1820. En el presente trabajo nos proponemos analizar cómo las nuevas entidades surgidas de la disolución del vínculo rey-súbditos utilizaron la idea del privilegio otorgado por un cuerpo soberano a fin de establecer prácticas de gobernabilidad legítimas. Estudiaremos principalmente las condiciones de la naturalización y el reconocimiento de la ciudadanía por los nuevos cuerpos políticos. Nos centraremos en el espacio del litoral rioplatense que constituía desde finales de silgo XVIII la Gobernación Intendencia de Buenos Aires. Desde los primeros años revolucionarios, en esta jurisdicción, comenzaron a plantearse tensiones que llevaron a la disolución progresiva de la Gobernación Intendencia (1814-1820). Podemos enmarcar entonces las entidades soberanas que se atribuían jurisdicción sobre los territorios que aspiraban gobernar: Buenos Aires - que bogaba por mantener la estructura del antiguo virreinato del Rio de la Plata - entre 1808 y 1820, la breve experiencia de la República Entrerriana (1820-1821) y las provincias Entre Ríos y Corrientes a partir de 1821.

\section{Las repúblicas del litoral rioplatense (1808-1821)}

Comenzaremos con algunas consideraciones respecto del empleo del término república utilizado en este período4. José Carlos Chiaramonte ha advertido sobre los riesgos de analizar vocablos, voces, expresiones, palabras del período, tales como ciudad, pueblo, estado, patria, república, nación, etc., "puesto que se trata justamente de una época en que siguen vigentes prácticas políticas que podríamos llamar 'de antiguo régimen', mientras se difunden otras correspondientes a la moderna teoría del Estado y los cambios derivados de la influencia de las revoluciones norteamericana y francesa»5. Las diferencias y similitudes entre provincia y república no tienen que ver

3 GOLDMAN, Noemí y TERNAVASIO, Marcela, «La vida Política», en GELMAN, Jorge (Coord.), Argentina, crisis imperial e independencia, Buenos Aires, Taurus, 2010, p. 78.

4 Para un análisis más detallado sobre la concepción de República en el Rio de la Plata puede en DI MEGLIO, Gabriel, República, in GOLDMAN, Noemí (editora), Lenguaje y revolución. Conceptos políticos claves en el Río de la Plata, 1780-1850, Buenos Aires, Prometeo, 2008, pp. 145-158.

5 Chiaramonte, José Carlos, Ciudades, Provincias, Estados: Orígenes de la Nación Argentina (1800-1846), Buenos Aires, Emecé, 2007, p. 114. 
solo con los espacios jurisdiccionales o territoriales. Como ha indicado Chiaramonte, en la etapa colonial, república podía responder a una ciudad y su jurisdicción. François Xavier Guerra ha planteado que el término provincia comenzó a ser cada vez más utilizado en el siglo XVIII, por lo que este no se presenta como algo inequívoco:

[...] pues puede referirse tanto a la estructura de la sociedad como a su gobierno por el Estado. En el primer sentido se interpreta frecuentemente como si existiesen comunidades humanas intermedias entre nivel superior del reino y otro local, que sería de la 'patria chica'. Pero [...] no existe en la Península hasta el siglo XVIII, y lo mismo pasa en América, una circunscripción territorial intermedia de gobierno civil entre el reino, por una parte, y los pueblos y ciudades, por otra ${ }^{6}$.

En el Río de la Plata, la definición de república podía referirse a la delimitación de un territorio determinado, sobre todo desde los decretos de Gervasio Posadas (1814) que dieron a Corriente y Entre Ríos carácter de provincias al desprenderse éstas de la Gobernación Intendencia de Buenos Aires. La intención de Buenos Aires (en tanto poder central) era otorgar un poder para ejercer una potestad inmediata en esos territorios, pero políticamente y jurídicamente la autoridad porteña pretendía subordinarlos. La desaparición del poder central y la caída de régimen de Intendencias dejaron a las ciudades cabeceras de las provincias, bajo su propia organización política y jurídica. Pero las jurisdicciones amplias, como las Intendencias, fueron parte de la ingeniería política improvisada con el nombre de repúblicas, jurídicamente más amplias que la provincia, aunque ahora limitada a las ciudades y sus entornos7.

No se trata entonces, de una concepción de república como oposición al régimen monárquico. Estas repúblicas provinciales tenían su antecedente en ideas de Antiguo Régimen, entendidas como comunidades políticas con ciertos derechos y niveles de autonomía local que a la vez, podían formar parte en un cuerpo superior. Por ejemplo, Covarrubias Orozco define una de las acepciones del término Cuerpo relacionado con «...una comunidad, como una república» dice en su Tesoro de la Lengua Castellana (1611)»8 . La República como un cuerpo político dotado de representación y autoridad propia continuó vigente a principios del siglo XIX. Por ejemplo, en las juntas andaluzas

\footnotetext{
${ }^{6}$ GUERRA, François Xavier, Modernidad e independencias. Ensayos sobre las revoluciones hispánicas, Madrid, Fondo de Cultura Económica, 2009, p. 96.

7 En las Provincias Unidas del Río de la Plata existieron dos experiencias breves que superpusieron su jurisdicción sobre otras provincias entre 1820 y 1821: La Republica del Tucumán y la República de Entre Ríos.

8 COVARRUBIAS, Sebastián de, Tesoro de la lengua Castellana o española, Madrid, Castalia, 1995, p. 380.
} 
la forma republicana se presenta como la única posibilidad ante la vacancia real (1808): «las juntas provinciales creadas por un pueblo reducido a la orfandad [...] reúnen legítimamente toda la representación, autoridad y poder. En una palabra, forman una república que tiene en depósito una monarquía»9. Los estados libres podían entenderse como Repúblicas pero, en el marco de la Monarquía Hispánica, eran compatibles en torno a las libertades de las ciudades y a los privilegios cedidos para el autogobierno en los asuntos locales o a nivel del reino. Otro ejemplo lo encontramos en el litoral rioplatense. En pleno conflicto con Buenos Aires Estanislao López manifiesta la idea de República en la Carta constitucional santafesina de 1819: "Queremos formar una República en el corto seno de nuestro territorio ${ }^{10}$. En este caso se pone de manifiesto la idea jurisdiccional y territorial de la época colonial, pero a la vez se destaca la creación de una comunidad política soberana y la posibilidad de constituirse en una entidad mayor a la que Estanislao López llama «esa gran Nación que esperan ambos mundos». Asimismo una vez derrotada Buenos Aires en la Batalla de Cepeda (1820) las jurisdicciones de Entre Ríos, Corrientes y las Misiones quedaron bajo una jurisdicción mayor que se llamó República de Entre Ríos. En estas nuevas entidades rioplatenses surgía el problema de reconocer los derechos civiles y políticos de los sujetos en relación con los nuevos poderes. Así, la definición de la ciudadanía y las posibilidades de naturalización se convirtieron en uno de los elementos clave para la consolidación de éstos espacios políticos.

\section{Vecindad, Naturaleza y privilegios reales}

Para abordar los problemas en torno a la persistencia de instituciones monárquicas en el Río de la Plata a principios del siglo XIX, es conveniente revisar algunos elementos inscriptos en la legislación y en las prácticas políticas entre los siglos XVI y XVIII. El ejercicio de los derechos de vecino y natural constituían lo más similar a la práctica de la ciudadanía política en el Antiguo Régimen. En los siglos XVI y XVII no se desarrolla la idea de ciudadanía ostentada por el individuo en tanto libertades y derechos, extendidos a todo el reino o a todo el imperio, sino que se vincula con la

\footnotetext{
9 La referencia es a PÉREZ GARZÓN, Juan Sisinio, Las cortes de Cádiz. El nacimiento de la nación liberal (1808-1814), Madrid, Síntesis, 2008; reproducido en: ROJAS, Rafael, Las republicas de aires. Utopía y desencanto en la Revolución de Hispanoamérica, Buenos Aires, Taurus, 2010, p. 96.

${ }^{10}$ Estatuto Provisorio Santa Fe, 1819. Para un análisis general de este estatuto ver TEDESCHI, Sonia, «Los últimos años de una institución colonial: el Cabildo de Santa Fe y su relación con otros espacios político-institucionales entre 1819 y 1832» in Revista de la Junta Provincial de Estudios Históricos de Santa Fe, 59, 1993, pp. 409-429.
} 
residencia en una ciudad, villa o pueblo determinados y bajo su leyes. La vecindad es diferente a la naturaleza, pues esta última tiene que ver con la proximidad a los poderes superiores. Por ejemplo, en el espacio castellano la adquisición de la naturaleza dependía del príncipe, ya que a la condición de natural se accedía por visto bueno del Consejo Real habiéndose presentado una solicitud de admisión dirigida al soberano ${ }^{11}$. Se advertía al Rey si había inconvenientes para concederla y las decisiones de éste, debían ceñirse a las Condiciones de Millones, que recordaba el problema que significaba el otorgamiento para la reserva de oficios a los naturales. Pero si el rey persistía en el pedido, ninguna de estas instituciones podía oponerse.

En el caso de los pedidos de vecindad sucedía algo similar. La vecindad implicaba la obtención de beneficios a los cuales sólo podían acceder quienes eran vecinos, pero los residentes podían avecindarse si cumplían ciertos requisitos formales y eran aceptados por la comunidad. En cuanto a los pedidos de avecindamiento de naturales que eran denegados por los concejos, los perjudicados comenzaron a recurrir a las chancillerías desde el siglo XVII pero esos, eran casos verdaderamente raros. Éste es un dato a destacar porque el rey podía llegar a otorgar naturaleza a un extranjero sin el consentimiento del Consejo Real o de las Cortes. Pero durante gran parte de la modernidad temprana se requería, no solo la aceptación por el Consejo Real, sino también el consentimiento simultáneo de las Cortes de Castilla.

Este funcionamiento se debía a que el monarca es regnícola en cada territorio y a la vez fuente de naturaleza ${ }^{12}$, ya que entre sus regalías se encuentra la de «naturalizar extranjeros para que gocen de los privilegios 'como si fueran naturales del reino', si bien esta facultad tenía que aplicarse por procedimientos muy diversos en los distintos dominios, con un grado variable de participación de las corporaciones territoriales». Lo dicho consta en el Diccionario de Autoridades cuando se define naturalización y naturalizar. El primero es «el derecho que concede el príncipe a los Extrangéros para que gocen de los privilegios como si fueran naturàles del Reino» y el segundo significaba «Admitir como natural al extranjero, en el propio País ò Lugar...», así como también «Conceder, ù dar à los extrangéros el privilegio de naturalización» ${ }^{13}$. Ambos términos no parecen estar definidos en un mismo sentido. Naturalizar aparece en las dos acepciones nombradas sin mención al otorgamiento del príncipe por el cual se

${ }^{11}$ CARZOLIO, María Inés, «En los orígenes de la ciudadanía en Castilla. La identidad política del vecino durante los siglos XVI y XVII», in Hispania, 62, 2002, pp. 646.

12 ÁLVAREZ-OSSORIO ALVARIÑO, Antonio, GARCÍA GARCÍA, Bernardo José (eds.), La monarquía de las naciones. Patria, nación y naturaleza en la Monarquía de España, Madrid, Fundación Carlos de Amberes, 2004, p. 31.

${ }_{13}$ Real Academia Española (RAE online), véase en Diccionario de Autoridades (1734), URL: < http://web.frl.es/DA.html > [consultado el 11 de diciembre de 2013]. 
define naturalización, por lo que naturalizar podría estar refiriendo tanto a la autorización regia como al consentimiento del Concejo ${ }^{14}$. Esta regalía propia de rey -la de naturalizar extranjeros- tenía su simbolización en el palacio real y la Corte. Esto ocurría con los Habsburgo entre los siglos XVII y XVIII, a los extranjeros se les podía otorgar la naturaleza a fin de que pudieran disfrutar de ciertos derechos y privilegios pero para todo lo demás seguían siendo extranjeros. Esto posibilitó que existieran diversas clases de cartas de naturaleza. Como ha señalado Tamar Herzog: «La primera naturaleza era absoluta y permitía a los extranjeros disfrutar de los derechos de los naturales sin limitación alguna; la segunda carta, sólo les habilitaba para obtener cargos públicos; la tercera, sólo permitía su acceso a un beneficio eclesiástico determinado, y la cuarta concedía acceso a un cargo público específico ${ }^{15}$. Pero esta pluralidad de naturalezas tiene orígenes medievales. Xavier Gil Pujol ha mostrado que en las Partidas se distinguía entre naturaleza como condición legal plena y natura, como nacimiento o descendencia, elementos a los que también se les reconocían consecuencias jurídicas. También señala que en las Partidas se «enumeraban una lista de diez tipos diferentes de naturaleza: 'La primera e la mejor es que an los omes a su señor natural'. Vasallaje, crianza, casamiento y residencia también figuran en la lista» ${ }^{16}$. La Constitución de Cádiz (1812) introdujo cambios en la organización política española a principios del siglo XIX, como la idea de ciudadanía. Sin embargo, ésta contenía caracteres que la enlazan con la antigua naturaleza. La condición de español se construyó históricamente a partir de la figura del natural y esta última a partir de la figura del vecino con la inserción en una comunidad vecinal, y la integración basada ahora en criterios de ascendencia y lugar de nacimiento que se convertirían en el sustrato que regulará los mecanismos de inclusión/exclusión de la ciudadanía ${ }^{17}$. Pero no se trata solo de los derechos civiles y políticos de los individuos que arrastran una continuidad corporativa, sino de que la concepción corporativa estaba fundada en gran parte en los antiguos lazos de la vecindad y de la naturaleza ${ }^{18}$. Por lo tanto, la

\footnotetext{
${ }^{14}$ SALVATTO, Fabricio Gabriel, «Vecinos, naturales y súbditos. La representación política en España peninsular entre el final de la dinastía Habsburgo y el comienzo de la era Borbónica», in Trabajos y Comunicaciones, 37, 2011, pp. 221-248, p. 229.

15 HERZOG, Tamar, Vecinos y extranjeros. Hacerse español en la Edad Moderna, Madrid, Alianza, 2006, p. 126.

${ }^{16}$ GIL PUJOL, Xavier, «Un rey, una fe, muchas naciones. Patria y nación en la España de los siglos XVI-XVII», in ÁLVAREZ-OSSORIO ALVARIÑO, Antonio, GARCÍA GARCÍA, Bernardo José (eds.), op. cit., p. 50.

17 HERZOG, Tamar, op. cit., p. 18.

${ }^{18}$ He hablado de ello en: SALVATTO, Fabricio Gabriel, CARZOLIO, María Inés, «Naturaleza y ciudadanía. Referencias y representación del súbdito al ciudadano» in Actas del VIII Jornadas de Historia Moderna y Contemporánea, Buenos Aires, Facultad de Filosofía y Letras, 2012, p. 10.
} 
concepción corporativa no sería un residuo en la Constitución de 1812 sino que fue parte necesaria en el marco normativo al que pudieron llegar los diputados doceañistas y que volvió a tener vigencia entre 1820 y 1823.

\section{Otorgamientos y rechazos de privilegios en el Río de la Plata (1810-1819)}

El período 1810-1813 ha sido conocido como el de la «máscara de Fernando VII» para referirse a las dudas surgidas en los rioplatenses sobre una ruptura integral con la dinastía borbónica al compás de los sucesos europeos. Por ejemplo, en 1811 la Junta Conservadora sanciona un reglamento advirtiendo que «Los diputados de las provincias unidas que existen en esta capital, componen una Junta con el título de Conservadora de la soberanía del Sr. D Fernando VII, y de las leyes nacionales, en quanto no se oponen al derecho supremo de la libertad civil de los pueblos americanos» (Art. 1). Por un lado se sostiene la soberanía del rey y por otro se remarcan las leyes nacionales, vale decir que en nombre de Fernando VII se ejerce la soberanía de la nación. El reconocimiento de esta soberanía del rey desaparece prácticamente en 1813. El vínculo del rey con los naturales se mantenía pero comenzaba a plantearse su reemplazo por el establecimiento de las "leyes nacionales" sostenidas por el gobierno revolucionario. Una de las herramientas clave para dicho remplazo consistió en el otorgamiento de la Carta de ciudadanía.

Las autoridades de la Asamblea General Constituyente de 1813 otorgaron Títulos de ciudadanía - como se nombran en las fuentes- a ciertos extranjeros para poder ejercer cargos públicos, pero también se los negaron a otros. En la sesión del día 3 de febrero de 1813 se sancionó un decreto para remover a los extranjeros españoles, pero a la vez, se planteaban excepciones: «En esta misma medida ha mostrado también la Asamblea la imparcialidad de sus designios, distinguiendo con el titulo de ciudadanía á todos los españoles europeos que han adquirido un derecho incontestable á la gratitud americana»19. Este otorgamiento de «título de ciudadanía» era, en cierta forma, semejante a una Carta de naturaleza como las otorgadas en el Antiguo Régimen por la autoridad soberana puesto que en el otorgamiento no se corroboraban criterios de residencia por determinada cantidad de años, ni por edad, ni por tenencia de un patrimonio inmueble o por ser propietario de un monto de dinero que le permitiera ejercer oficio útil. Es posible que quien pidiera la Carta de ciudadanía, cumpliese todas

19 LAMBRÉ, Tomás (Coord), El redactor de la Asamblea del año XIII, Buenos Aires, Del nuevo Extremo, 2010, p. 18. 
o algunas de las condiciones exigidas, pero lo que destacamos es que existiera la posibilidad de otorgar la ciudadanía a partir de un servicio de $\operatorname{armas}^{20}$.

La intención de los representantes reunidos en la Asamblea del año XIII, era lograr la sanción de una Constitución para las Provincias Unidas. Si bien este objetivo no se concretó, entre 1815 y 1819 se promulgaron los Reglamentos Provisionales, basados en algunos antecedentes planteados en 1812, como el «Proyecto de Constitución para las provincias del Rio de la Plata, formado por la Comisión especial»²1. En el Artículo 2 del Estatuto Provisional de 1815 se afirma: «Todo hombre libre, siempre que haya nacido y resida en el territorio del Estado, es Ciudadano; pero no entrará al ejercicio de este derecho, hasta que haya cumplido 25 años, o sea emancipado». También lo era «Todo extranjero de la misma edad, que haya residido en el país por más de cuatro años [...]» (Art. 3, Cap. III).

Las condiciones eran semejantes a las de la obtención de la vecindad por parte de un forastero, teniendo como primer requisito la residencia por más de cuatro años. Pero también se exigía que el solicitante «se haya hecho propietario de algún fondo, al menos de cuatro mil pesos, o en su defecto ejerza arte ú oficio útil al país, gozará de sufragio activo en las asambleas, o comicios públicos, con tal que sepa leer y escribir». Obsérvese que se reconocía el voto activo para los casos de los extranjeros con las condiciones antes nombradas, pero se contemplaba la posibilidad de que obtuvieran el voto pasivo como se especifica en el Artículo 4 (Cap. III): «A los diez años de residencia tendrá voto pasivo, y podrá ser elegido para los empleos de República, mas no para los del Gobierno: para gozar de ambos sufragios debe renunciar antes a toda otra Ciudadanía». Éste era un requisito antiguo de la vecindad. La renuncia de la ciudadanía extranjera era condición necesaria para poder ejercer el voto activo y pasivo pero no alcanzaba a los cargos de gobierno. Sin embargo, para el caso de los españoles europeos ambos sufragios quedaban en suspenso: «Ningún español europeo podrá disfrutar del sufragio activo o pasivo, mientras los derechos de estas provincias no sean reconocidos por el Gobierno de España» (Art. 5, Cap. III).

Lo planteado en el Artículo 6 se corresponde con algunos de los decretos de la Asamblea General Constituyente de 1813, puesto que nuevamente surgieron las excepciones: «Los Españoles sin embargo decididos por la libertad del Estado, y que

${ }^{20}$ SALVATTO, Fabricio Gabriel, BANZATO Guillermo, «Poderes locales y gobierno central ante el cambio de régimen en Buenos Aires: cartas de ciudadanía, cargos públicos y práctica de oficios, 1812-1815", in Actas VII Jornadas de Historia y Cultura de América, II ${ }^{\circ}$ Congreso Internacional y $I I^{o}$ Encuentro de Jóvenes Americanistas, Montevideo, Universidad de Montevideo, 2013, p. 9.

${ }^{21}$ Véase en: URIEN, Carlos, Soberana Asamblea General Constituyente de 1813, Buenos Aires, Maucci Hermanos, 1913, pp. 321-326. 
hayan hecho servicios distinguidos a la causa del País gozarán de la Ciudadanía; pero deben obtener la correspondiente Carta, que expedita por ahora hasta el Congreso General $^{22}$ el Jefe respectivo de la Provincia asociado del Ayuntamiento de su Capital». Obsérvese que no habiendo tal Congreso General, el Cabildo queda a cargo del otorgamiento o rechazo de la carta de ciudadanía y la evaluación de las condiciones del aspirante. En el Estatuto de 1817 se modifican estos aspectos, puesto que el Congreso General Constituyente se había reunido en Tucumán en 1816. Además de declarar la independencia de las Provincias Unidas del Rio de la Plata el Congreso otorgó más prerrogativas generales al Director Supremo. La Constitución de 1819 concentraba atribuciones en el ejecutivo que, a pesar de la división de poderes tan identificada con los regímenes constitucionales modernos, fue rechazada en el resto de las provincias.

\section{La gracia real en las provincias del litoral rioplatense (1820-1824)}

Francisco Ramírez tenía el título de Supremo para gobernar la República Federal de Entre Ríos y procuraba dominar el espacio litoral teniendo como prioridad la organización militar estructurada en comandancias de armas²3. El Superior Gobierno se atribuía las facultades de justicia en todas las instancias, sin reconocer ámbitos superiores de apelación. El transeúnte, sea americano o extranjero, no podía establecerse en ningún departamento sin la autorización de los comandantes, quienes debían examinar «la condición del sujeto, su profesión y el trabajo a que quiera dedicarse para concederle su permiso», según consta en el Reglamento que ordenaba política y jurídicamente esta entidad.

Los nacidos o afincados en la República eran quienes potencialmente tenían todos los derechos. Pero el reconocimiento como ciudadano benemérito surge de los servicios de armas o del aporte de los frutos de su comercio para el Estado, elementos que expresaban los favores realizados a la corona durante el Antiguo Régimen, y que eran retribuidos con algún favor o privilegio. Puede observarse también en el Artículo 10 de Apéndice del reglamento que los comandantes y jueces de los departamentos

[...] cuidarán incesantemente de que todo vecino debe tomar el arado, y sembrar suficientemente así para el sustento de su casa y familia, como para extraer, vender

\footnotetext{
${ }^{22}$ Se reconocía esta situación hasta que se realizase el Congreso General Constituyente.

${ }^{23}$ En el Artículo 1 de Reglamento de la República de E. $R$ (Orden Militar) se establece que «El territorio de la República de Entre Ríos será dividido en tantos departamentos, cuantos el jefe supremo estime conveniente, designándole a cada uno su jurisdicción territorial». Estos departamentos serian gobernados por un comandante militar nombrado por el jefe supremo.
} 
los demás productos, a fin de reparar las urgencias indispensables; debiendo igualmente cada vecino poner por primer año cincuenta plantas de árboles frutales en sus respectivas posesiones.

Estas disposiciones dirigidas a la autosuficiencia a mediano o largo plazo se registran también en antiguas ordenanzas peninsulares. El comercio estaba fuertemente normado por el reglamento, pero la urgencia de reunir fondos para el Estado obligaba a éste a hacer concesiones a todo aquel que pudiese comprometerse con la República. El Artículo 12 del Orden Político disponía:

\begin{abstract}
Los extranjeros o americanos, que quieran establecer su comercio en algún pueblo o departamento de la República [...] deberán dar una fianza de un diez por ciento de sus intereses, cuya fianza deberá extenderse al término de cuatro años, en el cual se comprometerá a seguir la suerte de la República. [...] si en caso de invasión se hallase conforme a coadyuvar los esfuerzos del país por su defensa, lo avisará al jefe inmediato de su residencia; éste lo comunicará al superior gobierno, a quien corresponde levantarle la fianza, y darle a reconocer por un benemérito ciudadano de la república.
\end{abstract}

Como se observa, en la normativa entrerriana, reaparecen los rasgos del privilegio y de las ordenanzas municipales de los siglos XVI al XVIII.

Hacia septiembre de 1821 la República de Entre Ríos se disolvió y la Provincia de Corrientes recupera su autonomía y se sanciona una nueva carta constitucional más similar a las dictadas en la primera década revolucionaria. En Corrientes vemos ejemplos similares. Las condiciones de reconocimiento directo de la ciudadanía eran el nacimiento y la residencia, criterios característicos de la vecindad. Pero como venimos observando, la naturalización de un extranjero o de un residente de otra provincia de América, dependía del otorgamiento por parte de las autoridades en representación provincial (gobernador y asamblea legislativa) ${ }^{24}$. Desde el punto de vista de la normativa, los que debían obtener de Cartas de Ciudadanía eran los considerados «Extrangeros de América» y para su obtención debían jurar «en manos del Gobernador observar la Constitución del País, y defender a toda costa la Independencia de la antigua Metrópoli» (Art. $8^{\circ}$ Sec. II). Unos años más tarde, en septiembre de 1824, se ampliaba la posibilidad de obtener la ciudadanía como nativo en América: «Es

24 SALVATTO, Fabricio Gabriel, «La representación política en los vestigios del imperio hispánico: relaciones entre España y el Río de la Plata (1820-1824)», in Épocas, 5 ,2012, p. 24, URL: < http://p3.usal.edu.ar/index.php/epocas/article/view/1138/1380 > [consultado el 28 de diciembre 2013]. 
Ciudadano el que haya nacido en las Américas denominadas antes Españolas, y resida en el Territorio de la Provincia; pero no gozará del ejercicio activo, o pasivo, mientras no cumpliere la edad de veinticinco años, o fuese mancipado» (Art. 1; Sec. II Reglamento Constitucional Provisional). El criterio para la definición de la ciudadanía es más amplio respecto del reglamento de $1821^{25}$. Por un lado se plantea la ampliación del nacimiento pero, por otro se mantiene la condición de residencia, como se menciona en el Artículo 5: "Al gobierno toca exclusivamente otorgar la dicha Carta con previo informe de la Municipalidad, y audiencia del Síndico Procurador General». Como en el resto de las provincias, estas medidas eran proclives a generar tensiones entre autoridades municipales y provinciales.

Señalaremos un último ejemplo. Disuelta la República Entrerriana, Entre Ríos ahora organizada como Provincia - promulga en marzo de 1822 un Estatuto Constitucional definiendo los criterios de ciudadanía de esta forma:

Son ciudadanos y gozan de todos los derechos de tales, activos y pasivos en la Provincia, conforme á las declaraciones de este Estatuto, todos los hijos nativos de ella y demás americanos naturales de cualquier Pueblo ó Provincia de los territorios que fueron españoles en ambas Américas, que residan en ella de presente, y residiesen en adelante (Sec. XII, Art.109).

Es importante destacar los principios de autoridad con que el Gobierno Provincial ofrecía la naturalización, pues este privilegio solo competía al:

Congreso y Gobierno General de la Nacion con patente de las autoridades de aquella clase, que han, reconocído las Provincias anteriormente, ó de las que en adelante se constituyan. Serán tambien ciudadanos de la Provincia todos los españoles y estrangeros que les obtengan; debiendo presentarlas al Gobierno para que se tome razon de ellas en el Registro Cívico, que debe llevarse para este efecto, y se publique en la Gaceta para conocimiento general. Sin este requisito no tendrán efecto alguno, ni se aprovecharán los agraciados de su privilegio (Art. 110).

El remplazo de la gracia real por la de la Nación, se expresaba a través del conjunto de sus representantes, que son gobierno y congreso. En la provincia de Entre Ríos la naturalización la alcanzaban extranjeros y españoles a los que se exigía la residencia

25 SALVATTO, Fabricio Gabriel, «Independencia y Ciudadanía. Los casos de Santa Fe, Corrientes y Entre Ríos» in Actas de las VI Jornadas de Historia y Cultura de América, Congreso internacional y $I^{o}$ encuentro de jóvenes americanistas, Montevideo, Universidad de Montevideo, 2011, p. 288. 
explicitada en el artículo 109. Quienes tenían garantizada la naturaleza eran los vecinos residentes en la provincia. Para los reputados extranjeros se exigía la obtención de una Carta de ciudadanía. Pero esto era en realidad un proyecto, ya que en 1822 la posibilidad de naturalizar era competencia directa de la Autoridad Provincial. El reconocimiento era doble: a los vecinos de la provincia y por lo tanto naturales, y a quienes se les otorgaba la naturalización para gozar de las prerrogativas de los ciudadanos:

Los ciudadanos, además de los derechos declarados por la seccion anterior comunes á todos los habitantes de la provincia, tienen el de votar y ser votados en las asambleas populares, y por los gobiernos para los empleos de la provincia, bajo las escepciones que se dirán (Art. 111).

En 25 de enero de 1822 se firma el Tratado de Cuadrilátero entre las Provincias de Buenos Aires, Santa Fe, Corrientes y Entre Ríos. El cual en el Artículo Primero establece:

Queda sancionada una paz firme, verdadera amistad y unión permanente entre las cuatro provincias contratantes, cuya recíproca libertad, independencia, representación y derechos se reconocen y deben guardarse entre sí en igualdad de términos, como están hoy de hecho constituídas, sin que por este acto solemne se gradúen renunciados los que defiende Santa Fé sobre el territorio de Entre Ríos, por documentos legítimos y amparos superiores, cuya reclamación legal, como las competentes a las demás de los suyos y respectivos, son el soberano legítimo Congreso General de todas las provincias en la oportunidad que presente el orden de los sucesos americanos en su perfecta tranquilidad y absoluta cesación de oscilaciones políticas, cuyas innovaciones convenientes serán obedecidas como emanadas de la soberanía nacional ${ }^{26}$.

Este acuerdo consolidó la autoridad del «soberano legítimo Congreso General de todas las provincias». En 1824 se llama a todas las provincias a un nuevo Congreso General donde nuevamente surgirán tensiones en torno a la autoridad soberana.

Se ha señalado, no sin cierta mirada teleológica, que la República Argentina se consolidó como Estado Nacional entre 1810 y 1880. Según esta visión, la igualdad ante la Ley, la condición de ciudadanía reconocida para todos los nacidos - varones mayores

${ }^{26}$ VARELA, Florencio (comp.), Biblioteca del comercio del Plata, t. IV, Tratados de los estados del Rio de la Plata y constituciones de las repúblicas sud-americanas, Montevideo, F. Varela, 1848, p. 22. 
de edad por supuesto - en los territorios del Estado tardó 70 años en cuajar completamente. Otras investigaciones centraron el foco en la vecindad como base de la construcción de los Estados provinciales luego de la caída del poder central entre 1819 y $\mathbf{1 8 2 0}^{27}$. También se han reconocido persistencias de Antiguo Régimen que eran consideradas resabios que las nuevas entidades republicanas debían superar ${ }^{28}$. Sin embargo, conviene enumerar algunos elementos destacados en este trabajo para verificar que estos resabios del antiguo orden, constituyeron los canales sobre los cuales se organizaron normativamente las nuevas entidades soberanas: otorgamientos discrecionales de privilegios, reconocimiento y pago de servicios y juramentos sobre las manos de los gobernadores. Este último elemento, como el señalado en los reglamentos correntinos de 1821 y 1824 constituye una muestra de las representaciones simbólicas en el reconocimiento a una la autoridad superior.

27 Véase por ejemplo: CANSANELLO, Orestes Carlos, De súbditos a ciudadanos. Ensayo sobre las libertades en los orígenes republicanos. Buenos Aires, 1810-1852, Buenos Aires, Imago Mundi, 2003; CHIARAMONTE, José Carlos, TERNAVASIO, Marcela, HERRERO, Fabián, «Vieja y nueva representación: los procesos electorales en Buenos Aires», in ANNINO, Antonio (Ed.), Historia de las elecciones en Iberoamérica, Buenos Aires, Fondo de Cultura Económica, 1995.

28 Lo explica en su texto: CHIARAMONTE, José Carlos, «Ciudadanía, soberanía y representación en la génesis del Estado argentino», in SÁBATO, Hilda (Coord.), Ciudadanía política y formación de las naciones. Perspectivas históricas de América Latina, México, Fondo de Cultura Económica, 1999, p. 54. 


\section{* El autor}

Fabricio Gabriel Salvatto es Profesor y Licenciado en Historia por la Universidad Nacional de la Plata (UNLP). Becario Doctoral del CONICET bajo la dirección de Dr. María Inés Carzolio y el Dr. Guillermo Banzato; es miembro del Centro de Historia Argentina y Americana (CHAyAIdIHCS CONICET) y de la Asociación Argentina de Investigadores en Historia (AsAIH). Es Profesor de Historia del siglo XX en el Instituto José Manuel Estada (IJME, City Bell). Entre sus líneas de investigación están: Vecindad, naturaleza y ciudadanía en mundo hispánico (XVIII y XIX siglos); Inclusión y exclusión de cargos públicos en ciudades, villas y pueblos en los cambios de regímenes en el litoral rioplatense (1808-1831).

URL: < http://www.studistorici.com/progett/autori/\#Salvatto >

\section{Per citare questo articolo:}

SALVATTO, Fabricio Gabriel, «La gracia real bajo la forma republicana en el Rio de la Plata. Vecindad y naturaleza en el litoral rioplatense (1808-1824)», Diacronie. Studi di Storia Contemporanea : Le monarchie nell'età dei nazionalismi, 29/12/2013,

URL:<http://www.studistorici.com/2013/12/29/salvatto_numero_16/ >

Diacronie Studi di Storia Contemporanea $\beta$ www.diacronie.it

Risorsa digitale indipendente a carattere storiografico. Uscita trimestrale. redazione.diacronie@hotmail.it

Comitato di redazione: Marco Abram - Jacopo Bassi - Luca Bufarale - Alessandro Cattunar - Elisa Grandi - Deborah Paci - Fausto Pietrancosta - Matteo Tomasoni - Luca Zuccolo

Diritti: gli articoli di Diacronie. Studi di Storia Contemporanea sono pubblicati sotto licenza Creative Commons 2.5. Possono essere riprodotti a patto di non modificarne i contenuti e di non usarli per fini commerciali. La citazione di estratti è comunque sempre autorizzata, nei limiti previsti dalla legge. 